\title{
On Religious Intolerance in Yorùbá Society: An Exploration of the Pluriverse Alternative
}

\section{Emmanuel Ofuasia csp \\ ORCID iD: https://orcid.org/0000-0002-2028-6005}

\begin{abstract}
In recent times, conflicts and extremism linked to Abrahamic monotheisms have reached an alarming level, both nationally and internationally. The Yorùbá, aboriginals in south-west Nigeria, have experienced an unfair share of this horrid trend. Unfair, because the intrusion of Christianity and Islam into Yorùbá life contributed to upsetting the serenity and spiritual balance of the people. Forced conversion, faiths preaching hate towards and inferiority of other faiths, and many other ills that are characteristic of these 'foreign' religions have been imported into Yorùbá society. The consequence of the arrival of these ideological differences into the Yorùbá space-time has not only caused religious conflict, but unnecessary and needless homicide. In this study, I employed the method of critical analysis and interpretation and I propose a pluriverse perspective that emphasises an understanding of contemporary African realities within religio-cultural and spiritual experience, which I explored as groundwork. Specifically, this study proposes Orị̀̀à propriety in traditional Yorùbá religion and spirituality as a paradigm to resolve conflict and achieve peaceful coexistence with the imported faiths that wield such influence in Yorùbá society.
\end{abstract}

Keywords: Africa, Òrị̀à, peace studies, religion, Yorùbá, spirituality.

\section{Introduction}

'My daughter will not marry a kiriyo!', ${ }^{1}$ Fadilat Abdul-Jeleel Òșúntọ́lá, the chief imam of the community's central mosque, pronounced to his followers,

${ }^{1}$ Yorùbá slang for Christian. 
when he was informed of his daughter's emotional proximity to Peter Fásínà, the son of one of his numerous tenants, who professes and practices the Christian faith. But Fatimah is in love with Peter. And Fatimah is the one and only daughter of Fadilat Òșúntọ́lá. There are some similitudes between the families: They reside in Ilésà, in Ồșún State, Nigeria. They are Yorùbá, albeit thoroughly steeped in the respective tenets of Islam and Christianity. What is remarkable is that, after several months of fervent resistance, and as a result of endless pleas and evidence of affection, the fadilat recants to grant his approval, though subject to a condition: 'Pétérù!' My daughter will remain a Muslim and practice the Muslim faith if you marry her. Do you agree?' This seemed a reasonable condition. Peter was in love too, so he consented. The wedding was grand and everyone was happy.

Five years after the wedding, Fadilat Abdul-Jeleel Òșúntọ́lá died in his sleep. Over time, Peter's reputation as a powerful man of God has brought him rapid promotion within his Christian denomination. On the other hand, Fatimah still wears her hijab, as if she is married to a Muslim. The promise to the fadilat seems not to have been compromised, however, things soon took a turn for the worse.

Peter was told that, before he could be appointed as the head of all the churches in that district, he had to convert his wife to Christianity. What kind of pastor heads a district with a Muslim for a wife? Technically, his wife's faith is an impediment to his calling. So, he starts pressuring Fatimah: 'Since your father, to whom I made the promise, no longer lives, of what use is the condition? The condition no longer holds weight. You MUST become a Christian, accept the Lord Jesus and be saved!' However, Fatimah was not willing to trade her Muslim faith, and a standoff develops.

To avoid using a gallon of words for a spoonful of thoughts, the consequence is that the marriage is no longer what it used to be. Two entities that had been deeply in love, initially separated by religion, but who had seemingly transcended their differences, are now faced with the existential realities of life. After concerted efforts to convert her to Christianity failed, domestic violence enters the fray. Furthermore, another crucial decision has to be made about a sensitive subject: Should their four-year-old daughter attend islamiyyah, or Sunday school? They argue over the school and the child's dress. On the domestic front, Peter wants to be intimate with his wife,

${ }^{2}$ Yorùbá equivalent of the Biblical name, Peter. 


\section{Emmanuel Ofuasia}

but 'it is the Holy month of Ramadan', Fatimah insists. Peter can no longer cope; he started to see and imagine things he had hitherto bracketed as otiose. Finally, he admits to himself: 'I am married to an enemy of the Gospel'. Gradually, the love between the couple started to decline rapidly. In the end, things fell apart as the centre could not hold. They had to go their separate ways, because no compromise was possible between the demands of their faith and their love.

Experiences of this type are not limited to the Yorùbá parts of Africa, but are endemic in almost all parts of Africa, and even the world. In the face of the tragic end of the love between Fatimah and Peter, I contend that, had the spirit of cohesion, mutual love, tolerance and charity, which is indicative of traditional Yorùbá religion, been employed, the love story would not have evolved into a tragedy.

We have established one thing: both Fatimah and Peter are Yorùbá persons. Their surnames say more about their family history and background than the Abrahamic monotheisms they profess. I postulate that, had they been able to tap into their rich traditional and religious heritage as Yorùbá, perhaps their marriage would not have crashed. It is clear that religious skirmishes that have been ushered into Yorùbá life by Abrahamic monotheisms have done more harm than good. What is even more unfortunate is that the foremost theoretical framework usually foregrounded for succour - religious toleration and pluralism - has not been effective. It is for this reason that I propose a pluriverse perspective that emphasises comprehending contemporary African realities within their religio-cultural and spiritual experience, as a plausible possibility of resolving conflicts, and achieving peaceful and mutual co-existence.

At this juncture, a critic could ask: What is the pluriverse theory about? How does it intersect with traditional Yorùbá religion and spirituality? Will it serve as a suitable, adequate and applicable framework for saving marriages, lives, and relationships, like that of Fatimah and Peter? Can it promote peaceful relations and snuff outbursts of religious conflict, which are now commonplace in contemporary Yorùbá life?

In the pages ahead, I initiate a groundwork that will answer each of these questions in the third part of this study. In the second part, I explore the application and limits of the principles of toleration and religious pluralism, which is the most widespread and accentuated position endorsed by scholars as a paradigm for conflict and altercations resulting from religion. There have 
been torrents of scholarly articulation on the subject of religious pluralism and toleration. My aim is to engage with this articulation in order to provide an explanatory justification for the pluriverse option, which I admit. In addition, I uncover the aggregate submission of scholars in relation to the perspective of religious toleration and pluralism, and its suitability and utility within Yorùbá space-time. This approach is in line with 'the pragmatic maxim of Pierce and James that, if an idea cannot be lived in practice, it should not be affirmed in theory' (Griffin 1998:2). The fourth section concludes this inquiry.

\section{Applying the Thesis of Religious Pluralism and Toleration to Nigerian [Yorùbá] Society: Exposing Flaws and Limits}

The Yorùbá are aboriginals of the south-western part of modern-day Nigeria (Atanda 1990:1). The religious life of the people involves a triad of Christianity, Islam and traditional religion (Isichei 1983). Whereas Christianity and Islam are dominant and influential in the lives of the people, traditional religion has been on the defensive. It is important to note that, in Nigeria, available record indicates religious conflict to be endless and spontaneous as notable towns, and the years they engaged in religious conflict, post-independence, have been documented in the research of Fatima Nuzhat (2014) thus: the Maitatsine riots in Bulumkutu (1982); the MoonEclipse crisis in Borno (1996); Kaduna (Maitatsine riots in Rigassa 1982; 1992; 2000); Tiv and others in Nassarawa (2001); Jos (1994; 2000; 20012003; 2008; 2009; 2010); Ikulu-Bajju (2001); the Maitatsine riots in Jimeta (1984); Kano; Maitatsine $(1980 ; 1982 ; 1987 ; 1990 ; 1995)$ Maitatsine riots in Gombe (1985; 1991); Illorin religious conflict (1986); Jalingo (1992; 2009); Maiduguri (2006; 2009) Iggah-Oyikwa (2002); Kano(2004); Numan (2004); Azare (2001); Bauchi (2010); Shagamu (1999); Kafanchan (1987); Tafawa Balewa (1991; 1995; 2001); Zangon-Kataf (1992); Tiv-Jukun and Tiv-Kuteb (1992-1993); Potiskum (1994; 2009); Kuteb-Chamba (1997-1998); IgbirraBassa (1986-2000); Yelwa-Shandam (2002; 2004); Mangu-Bokkos (19921995); Bukuru-Gyero (1997); Ibadan (2010); and Wukari (2010).

Furthermore, it has become almost the norm that the way people are treated in Nigeria, largely depends on the faith (Christianity or Islam) they profess but closely followed by what ethnicity they hail from. How can these religions preach peace and love, but do the opposite in society? An attempt 


\section{Emmanuel Ofuasia}

has been made to explain this phenomenon:

These religions cannot bring peace and tranquillity to our beloved country, to any country. The history of Christianity in Europe, the Crusades, the obnoxious inquisition, the Jihads, the bloody Iranian Islamic Revolution, the Maitatsine religious revolt in Kano in 1981 are all pointers to this hard fact. These religions proclaim peace in churches and mosques but outside them they are doing exactly the opposite of what they proclaim. They are only religions of words and precepts, not of deeds (Mala \& Oseni 1984:2-3).

The direct and non-direct causes of these clashes, to my mind, are ingrained in the four distinctive features of Christianity and Islam. I will explore them in the next section. For the moment, it is crucial to relay too that the conflicts usually involve Muslims and Christians leading to loss of precious lives and properties. More so, it is important to not wish away the increase in 'the feeling of hatred among both religions' (Nuzhat 2014:16). It also needs to be on record that,

the overwhelming majority of Muslims and Christians are moderate in their interfaith relations. Only the extremists have taken to violent conflict. The current Boko Haram crises throughout the North, and increasingly throughout the Middle Zone of the Federation, have the potential to destabilize the entire country, however (Paden 2015: 9).

Since Nigeria is a heterogeneous society, I do not boast to have a theoretical framework that can work for all shades. As a result, I limit my investigation to the south-western part of the country, which is dominated by the Yorùbá.

What makes intolerance rife between Christians and Muslims? What theoretical frameworks are in place to check the excesses of religious intolerance? How plausible and adequate are they, especially within the African space-time?

Discourses on the subject of religious toleration and pluralism has various aims, among which the intention of making the world a better place, devoid of antagonism, coercion, and discrimination, and irrespective of the religious views professed and/or practiced. It is, therefore, not surprising, as John Hick (2010: 717) claims, that, 
the whole subject, within philosophy of religion, of the relation between the religious traditions presents so obvious a challenge to a dominant contemporary form of confessional religious apologetic, that it seems inevitable that it will be increasingly widely discussed in the coming decades.

However, before engaging critically with the foremost articulations comprising the discourse, it is important to have a working comprehension of the concepts toleration and pluralism. In the words of E. Langerak (2010: 606),

Toleration is the enduring of something disagreeable. It involves a decision to forgo using powers of coercion, so it is not merely resignation at the inevitability of the disagreeable, although begrudging toleration can be granted when one believes that coercion, while possible, would come at too high a price.

To appreciate the inner kernel of toleration to be attained, knowing the meaning of tolerance could be helpful. This is important to clear the air of confusing toleration and tolerance as necessary synonyms. To this end, Thomas Scanlon (1996: 226) helps with this idea by stating that 'tolerance requires us to accept people and permit their practices even when we strongly disapprove of them. Tolerance thus involves an attitude that is intermediate between wholehearted acceptance and unrestrained opposition'. The implication is that whereas tolerance involves the mere acceptance of the other, toleration goes deeper as it tasks one to understand the other in addition to mere acceptance. It places premium on having a core comprehension of perceived disagreements with the aim of transcending same. So for this discussion, toleration will be the focus not tolerance.

As a result of this conceptual exposition, I conclude that religious toleration, then, 'generally applies to expressing or acting upon theologicallyrelated beliefs, although the mere holding of beliefs or the persons holding them have also been the objects of intolerance and toleration' (Langerak 2010:606).

Pluralism, on the other hand, refers to a position that rejects the privileging of any one value or worldview over all others. This is because pluralism accords inherent value to a diversity of perspectives. Pluralism goes 


\section{Emmanuel Ofuasia}

'further than tolerance in that it rejects the hierarchal privileging of one's own position over the others as morally and politically problematic' (Erlewine 2010: 8). Religious pluralism can, then, be understood as an ideological framework that gives equality to or acknowledges the equality of all religions, without placing one higher or above another. It should, however, be emphasised that, regardless of the demarcation between religious toleration and religious pluralism, both concepts acknowledge the necessity for respect for and the dignity of the religious world-views of one by another (Hick 2010:719).

Having exposed the meaning of toleration and pluralism, what, then, is intolerance? Intolerance may be perceived as, 'the unwillingness to suffer the otherness of the Other, the unwillingness to limit the implications of one's worldview in order to make room for the Other and her worldview' (Erlewine 2010:9). In plain language, it means the failure to appreciate the thought system of the other, given the prejudice that one's own outlook is superior.

The denigration and prejudice directed at the thought system of the other, I maintain, is responsible for the spate of intolerance exhibited by some religious adherents. I propose that this lack of toleration has culminated in torrents of reports about religious conflicts, loss of life and valuables, as well as a total disregard for humanity and nature, all in the name of protecting the sacredness of God and what the Divine entity represents. It cannot be denied that, even among the Abrahamic monotheisms, fissures and disagreements as a result of lack of toleration are rife. In social life, the consequence is cases of persuasion, discrimination, segregation, antagonism and, worst of all, coercion and violence against the other, the one who does not share the same ideas about the Divine as held by adherents. My contention is that there is a structural antagonism against the other that thrives unchecked. By the other, I mean individuals or groups of individuals who do not profess a particular faith.

Given the above antecedent, philosophers, religionists, liberals and other concerned scholars have articulated variants of theories that have come to be branded under the label of religious toleration and/or religious pluralism. Foremost scholars who have contributed to the subject matter are Jean-Jacques Rousseau (1997), John Locke (1983), J.S. Mill (1978); highly influential scholars are John Hick (1989; 1985; 1980), John Cobb Jr. (1999), Jürgen Habermas $(2002 ; 1996)$ in the preceding century, and Robert Erlewine (2010) within the last decade. The aggregate verdict deriving from these 
scholars is that, 'calls for tolerance and pluralism either go unheeded or only further exacerbate the situation, given that those who make them fail to take into account the contours of the symbolic or discursive structure shared by the Abrahamic religions' (Erlewine 2010:3). What, then, are the basic similarities of the Abrahamic religions/monotheisms? Is it the case that these shared similarities have the potency to solve inter-religious conflict, even in Yorùbá society? Can they promote mutual cohesion and save the marriage of Fatimah and Peter? Perhaps they can; the rest of the present section is committed to these three questions.

According to Martin Jaffee (2001:759), 'Judaism, Christianity, and Islam are equally rich, historical embodiments of a single structure of discourse that underlies the historically developed symbol systems specific to each community'. This implies that, in each of these faiths, there are some common denominators,

whose metaphysical underpinnings follow a logic that is rooted in a tense dynamic between particularity and universalism, wherein a particular community is imbued with universal significance, and as a result is brought in conflict with all other particular communities, which lack this universal significance (Erlewine 2010:10).

These metaphysical underpinnings, which form the common denominators among these faiths, manifest in four ways: revelation, election, historical mission, and eschatology (Jaffee 2001; Erlewine 2010)

Revelation refers to the commonality that each of the three Abrahamic monotheisms derives from a supernatural encounter with the Divine. Robert Erlewine (2010:11) expatiates in this connection: 'In the moment of revelation, the universal God of creation becomes manifest to a particular community through an act of revelation'. The process of 'manifesting to a particular community' already attests to the quality of election. Judaism, Islam and Christianity each claims to have received the mandate to be used (elected) by the Divine as a voice for the rest of humankind. The entire trajectory of spreading and adding converts from all corners of the planet to their ranks is suggestive of the historical mission. The three monotheisms also share the eschatological view - the outlook that the world will come to an end. Hence, the mission, throughout history, has been to propagate the end of the world and acquire as many converts as possible 


\section{Emmanuel Ofuasia}

for the Divine, who had elected the devotees of these monotheisms to follow the supernatural revelation.

As simple as these similarities are, I must hint that there is an implied tension and competition among the Abrahamic monotheisms, as each strives to muscle out the other as the one true path to the Divine. If Judaism claims to have been elected and entrusted with the historical mission, does Islam have a better voice, or does Christianity, for that matter?

At this juncture, it needs no elaboration to realise that, deep within the structure of each of the Abrahamic monotheisms, there is a tendency to repress and disdain, whether through force, persuasion or violence, whatever ideology that contradicts among them. Furthermore, within each of these monotheisms, there is an inherent tension, which found further extension in Yorùbá land. However, before examining the impact of this interference on the relegation and abandonment of traditional Yorùbá religion and spirituality, the position of scholars in this regard is pertinent.

The four common denominators of the Abrahamic monotheisms are not consistent with the thrusts of religious toleration and pluralism championed by renowned and erudite persona like John Hick (1989; 1985; 1980). This means, religious people who adhere to any of the Abrahamic monotheisms face a dilemma: They can accept the principles of pluralism and toleration, which may demand that they ignore the common denominators, and practice a 'reconfigured' religion away from the particular monotheism they profess and practice, or they can affirm an account of a monotheism that takes cognisance of the four denominators present in other monotheisms (Erlewine 2010:28). The implication of this claim is that a believer can either affirm the common denominators and suppress other religious truths, or make adjustments to her particular monotheistic faith for the sake of pluralism and/or toleration, and render these faiths inherently distorted. Scholars, such as John Hick (1989; 1985; 1980), John Locke (1983), Jean-Jacques Rousseau (1997), and Jürgen Habermas $(2002 ;$ 1996) have endorsed the latter disjunction. The implication of such an approach is that it initiates the Abrahamic religions away from their true, inherent natures. The view of John Hick is worthy of consideration. In his philosophy of pluralism, Hick (1985:42) announces that,

Yahweh and Shiva are not rival gods or rival claimants to be the one and only God, but rather two different concrete historical personae in 
terms of which the ultimate divine Reality is present and responded to by different large historical communities within different strands of the human history.

Elsewhere, he is even more explicit, and states that Christians,

can revere Christ as the one through whom we have found salvation, without having to deny other points of reported saving contact between God and man. We can recommend the way of Christian faith without having to disregard other ways of faith (Hick 1980: 75).

Hick gives less emphasis to the distinctive common denominators present among the Abrahamic monotheisms (Erlewine 2010). His solution endorses an unfair rendition of Christianity. My opinion is similar to the reflection of Robert Erlewine (2010: 21), who indicates that:

It is imperative to notice that while ostensibly operating out of an explicitly Christian, and therefore monotheistic framework, Hick has undermined or transfigured every moment constitutive of the basic structure shared by the Abrahamic monotheisms. Hick is able to reconcile Christianity with pluralism only by entirely shedding the discursive structure of the elective monotheisms, a move which he clearly does not view as problematic.

The aftermath of Hick's intellectual contribution to the discourse has inspired many conservative Christian theologians and apologetics, such as Pope Benedict XVI, to reject subscribing to what they perceive as Hick's stripping of the very essence of Christianity and the monotheistic thought system (D'Costa 1990; Ratzinger 2004). The point is that the debate will continue to generate diverse perspectives. It is my conviction that retaining these denominators provides a platform for tussles and conflict. It is important that the common denominators should be reviewed in the light of how they provide the breeding ground for conflict among the people whom they intend to save from impending disaster.

It is valid to hold that religious toleration and pluralism has not been wholly successful in the West either. Given this, is it likely to ever birth success among Africans, with their unique backgrounds and histories? 
Personally, I am not optimistic. I am not convinced of the possibility: African indigenous knowledge systems are unique and born out of the lived experiences of the people. That fact that they are African does not diminish the authenticity of their religious and spiritual perceptions. This is exactly what Godwin Sogolo (1993: 74) has in mind when he says that,

The mind of the African is not structurally different from that of the Westerner. Also, the contextual contrast between Western thought and traditional African thought, which considers only the former as a suitable material for philosophical reflection, rests on false premises. The truth is that both are similarly marked by the same basic features of the human species. The difference lies in the ways the two societies conceive of reality and explain objects and events.

The Western and African mind see reality from different perspectives. Hence, it will be a form of ideological superimposition if submissions of Western scholars on religious toleration and pluralism are brought to bear within the African space-time. Instances of religious intolerance and then violence exploding between African Christians and Muslims account for the lives that have been cut short. Africa is no longer at ease. If Africans do not take cognisance of religious toleration and pluralism, and curtail the conflict and violent potentials of the Abrahamic monotheisms, then it is pertinent to explore the African indigenous knowledge option, in order to seek a more plausible recipe that will bring them closer to the divine without violent confrontations without compromising their love for Christianity and Islam.

\section{Indigenous Knowledge on Conflict Resolution: A Pluriverse Account of Traditional Yorùbá Religion and Spirituality}

In this section, I expose a pluriverse approach to religious conflict and the quagmire that religious toleration and pluralism does not adequately comprehend, particularly, as it pertains to Africans. It is the thesis of the pluriverse that 'contemporary realities in Africa can be better understood within indigenous religio-cultural experience' (Kaunda, Luxman \& Hewitt 2018: 1). Via the framework of the pluriverse theory, I foray into indigenous Yorùbá religio-cultural experience, to extract a platform for checking religious intolerance and conflict in Yorùbá society. 
For the sake of the outlook that I intend to employ, it is instructive to commence by stating that 'scholars have argued that a lack of intentional contextualization of Islamic and African beliefs and practices within African world-views promoted dysfunctional interaction between these religious systems and the traditional African system of thought' (Kaunda et al. 2018:2). This outlook is shared by Mbiti (1969) and Sindima (1995). However, the repercussion is that the adoption of Christianity and Islam by Africans have caused them to be removed from indigenous systems that are capable of transcending the conflict and tussles that are characteristic of these foreign religions (Kaunda et al. 2018; Ramose 2012; Sindima 1996; Tafese 2016). Therefore, the demonstration by scholars that 'African approaches to reconciliation and conflict resolution are not monolithic, but rather dynamic and highly adaptive to the ever-changing socio-political landscape of the world' (Kaunda et al. 2018:3), comes as no surprise.

At this juncture, I offer that, even in the face of lack of consensus about a definition, I conceive African indigenous knowledge to be ideas or thought systems that are distinctively original to traditional Africa, but relegated by advances in Western science and episteme as otiose, antediluvian and chaotic. Such an unfair rendition has done more harm than good, and due to the failure of Western paradigms to solve religious conflict in Africa, it is my contention that a revival of some of these indigenous epistemologies may assist in overcoming some of the conundrums that plague contemporary Africans. It is also essential to note that, in an African indigenous approach to conflict resolution, there are no victors or vanquished, as all the individuals concerned aim to proffer humane panacea to the dilemmas and conundrums that initially nurtured the conflict (Bukari 2013; Kaunda et al. 2018; Ramose 2012; Querejazu 2016).

It is unfortunate, however, that, in spite of the bulk of literature on the discourse on how local epistemology can serve as a dais for conflict resolution, it has yet to be applied to the Yorùbá space-time. This is where this study diverges. I explore the pluriverse approach to serve as groundwork to harness the indigenous thought system to extinguish religious skirmishes. I employ this approach with the caveat that,

[i]ndigenous epistemology is not perceived as an alternative perspective but rather as an option that can function independently or 
concurrently, or with already existing universally favored perspectives and/or is inculturatively integrated within Christianity and or Islamic notions of reconciliation and conflict resolution' (Kaunda et al. 2018:3).

What, then, is the inner kernel of the pluriverse thesis? The pluriverse theory is an approach that acknowledges diversity, or the multiple ways in which reality can be understood and interpreted in relation to other perspectives (Kaunda et al. 2018: 3). It needs to be emphasised that, 'this perspective advocates a paradigm shift from the Western familiarized ontology and methods of discovering human realities, in favour of distinctive indigenous concepts for understanding reality' (Kaunda et al. 2018: 3). It is a perspective that connects with other ways of understanding and interpreting reality (Escobar 2010:9). The pluriverse theory rejects the domineering theories of the West as the final court of appeal. The pluriverse option offers an opportunity to examine critical issues with the yardstick of 'the natives' (Fanon 2008:4). The rest of this essay will present arguments that strengthen my case. The starting point then is to provide a concise understanding of traditional Yorùbá religion.

Contrary to the shades of atheism that is rampant in Western societies, the starting point of traditional Yorùbá religion and spirituality is the admission of the existence of Olódùmarè, the Supreme Deity. This is a contention that John Ishola Bewaji (2007: 369) entertains when he says that,

The existence of Olodumare is not geotactic, nor is it dependent upon any human whim. This, perhaps, explains why no elaborate arguments of proofs are thought necessary for the existence of God in Yoruba religion. The starting point of wisdom among the Yoruba is the acceptance of the de facto existence of Deity.

So, if the traditional Yorùbá takes the belief and existence of Olódùmarè as the starting point of their theology, how do they worship or adore this Deity? The consensus is that, in traditional Yorùbá religion, worship of God, the Supreme Being, Olódùmarè, is not direct, but channelled through the òrị̀às, that is, divinities. Furthermore, it is an incontestable claim that,

the divinities (called, variously, Imales or Irun-Males, or Orisas in 
the Ifá corpus) were the first creations of Olodumare; and that they were created by Him in His capacity as Eleda, for the primary purpose of assisting Him in the management of the planetary system (Akintola 1999: 52).

Olarenwaju Shitta-Bey proposes that this is suggestive of is that the divinities were created by Olodumare to assist ... That they are to assist suggests that they are deputising Olodumare, which make them all the deputies of Olodumare' (2013:79). Furthermore, 'the Orișa have specialized priesthoods and cults of worshippers/followers, whereas Olodumare has no specialized priesthood and his cult is either universal or nonexistent' (Ogunnaike 2015:226). This reveals that, in addition to the assistance rendered to Olódùmarè, the òrișàs are also the bridge through which Olódùmarè receives worship and supplications from humans (Ofuasia 2020).

The major òrișàs, or those whose worship has become widespread throughout various Yorùbá cities and the diaspora, include Obàtálá, the old, wise, and gentle arch-deity of white cloth who fashions the bodies of people; Eșù, the mischievous and powerful trickster deity of the crossroads, who delivers sacrifices to other òriṣàs, and serves as a divine 'policeman' and messenger; Ògún, the powerful, hot-tempered, solitary deity of iron, war, and justice; Órúnmilà, the wise and patient god of Ifá divination and messenger of Olódùmarè; Òsanyìn, the mysterious god of plants, medicine, and magic; Olókún, the deity of riches and the lagoon and/or deep sea, Șàngó, the fiery, proud god of thunder, lightning, and retributive justice, and Yemoja, the gentle, maternal goddess of the Ogun river in Nigeria, and the ocean and its fish in the New World (Ogunnaike 2015:227). It is obvious that these orișàs have a domain of influence from where they assist Olódùmarè to manage the universe.

It is also important to understand that there is no coercion between Olódùmarè and the òrị̣às. In other words, Olódùmarè persuasively, with reason and logic, tasks the òị̀sàs, who also possess the fallible characterisation of success or failure (Ofuasia 2019). This is demonstrated in the folklore where Olódùmarè commissioned Obàtálá with the task to create the universe, only for Obàtálá to slumber, as a result of an overdose of palm wine. The task was, later, assigned to Ôrúnmilà, who executed it quickly. This folklore is in stark contrast to God in the Abrahamic monotheisms, who does not only wield power coercively, but also has angels who are infallible. 


\section{Emmanuel Ofuasia}

While discussing the relation that exists between Olódùmarè and the òrișàs, the late Austrian-born keeper of the sacred OȘun grove in Oșogbo in presentday Nigeria, Susanne Wenger, expounds through Ulli Beier (1975:33):

Olodumare who contains all the complexities of the world within him. He is the egg from which the world breaks out. As a creator, Olodumare is called Elẹda ( $e d a=$ creature). With a gesture of creation Olodumare splits himself up and becomes a multiple being through his innumerable creatures. Olodumare in his pure form cannot be perceived by the senses or understood by intelligence that is why he receives almost no direct worship and no sacrifice. But as Elẹda we can begin to understand him ... In Susanne Wenger's vision, the orisha are part representations of Olodumare. Each orisha is the universe looked at from another angle. Olodumare is the sum total of all the complexities, he is the universe concentrated into one intelligence. Susanne Wenger says that one could conceive God as the force from which everything emergesor else one could see him as the coexistence of all the complexities.

The foregoing attests to the persuasive relation between Olódùmarè and the orișàs. And, since the orișàs are the mediators between humans and Olódùmarè, it follows that they are the ones to be worshipped. Each òrị̦à has its own unique and distinct ethos and taboos that adherents must observe, and which serves to keep the spirituality and status quo intact. Gentle, patient Obàtálá will punish his devotees for drinking alcohol. Ọrúnmilà, in spite of being persevering and empathetic, 'can punish his devotees who disregard his taboos by lying, committing adultery, etc.' (Ogunniake 2015:249). Ògún is swift to punish liars and oath-breakers, as is Sàngó, but no Orị̀à̀ is more volatile than Eșù.

Eșù is simultaneously a mischievous trickster and a strict enforcer of the will of Olódùmarè and the law of sacrifice. When a sacrifice is offered, it is Eșù who takes the sacrifice to the intended recipient, thus, the Yorùbá saying: 'Eni rúbo l'Eșu $n$ gbè', [Ėșù supports the one who sacrifices]. However, if a sacrifice is not made, or not done correctly, Eș̣̀ will side with the Ajogún (the malevolent spirits) and wreak all kinds of havoc on the offending party. Eșù also punishes the other òriṣàs for their refusal to 
sacrifice, for their hubris, and sometimes just for fun. Eșù is a notoriously ambivalent figure and is only consistently allied with Òrúnmilà, the god who prescribes sacrifices (Rowland 1994:45).

Eșù is both good and evil, a reflection, on a lower plane, of Olódùmarè's transcendence of both good and evil (Ogunnaike 2015:250). The chaos that Eșù is so fond of creating is a shadow of the undifferentiated 'chaos' of Olódùmarè's transcendence of all categories and divisions. Due to the fear he inspires and his sometimes malevolent behavior, Eș̀̀ was the name used to translate 'the Devil/ Satan' in the Yorùbá Bible. However, Eșù actually bears little resemblance to the tempting, evil Satan, or the devil of the Abrahamic traditions, unless one considers the more ambiguous, or even positive role he plays in some esoteric Abrahamic traditions (Massignon 1994:222f). This is why, for Olusegun Oladipo (2004:369) and Kazeem Fayemi (2012:312), the equating of Eșù with the Satan of the Abrahamic monotheisms is an example of conceptual superimposition, which must not be allowed to corrupt African traditional religion.

What I have done so far is to disclose the traditional Yorùbá notion of metaphysics, religion and spirituality. What I intend to point out, because it explains my pluriverse thesis, is that, in traditional Yorùbá religion and spirituality, there is no competition or antagonism among adherents regarding who serves Olódùmarè better. The traditional Yorùbá understands and tolerates, with reverence, the taboos, celebration, and worship of Olódùmarè through any òrị̀à. Someone who adores Olódùmarè through Sàngó never makes fun of or disregards someone who does same through $\hat{O}_{S ̣ n}$. In fact, the traditional Yorùbá mind is tolerant to the extent that the yearly celebrations of some òrișàs are graced by all and sundry, except where some activities during the celebration could diminish and invoke the anger of their original òrișà. A little amplification is needed here!

Consider the traditional Yorùbá who is celebrating the Ògún festival, for instance. Much as Obàtálá devotees are welcomed, they must refrain from taking the palm wine/alcohol that is served during the celebration. This is not because the jar or gourd used to serve is unclean, or that the Obàtálá faithful has personal grievances against the Ògún celebrants. The reason, which is not a subject of controversy, is clear among the traditional Yorùbá Obàtálá devotees do not consume liquor. They are not perceived as parading a faith or belief that is inferior - they are even accorded greater respect for keeping to the rules of their òrị̣à. Respect is necessary, because one angry 


\section{Emmanuel Ofuasia}

òriṣà that has been violated can wreak havoc on an entire community, irrespective of the individual orișà that others propitiate. This belief is in tune with Desmond Tutu's explanation of Ubuntu in the adage, 'A person belongs to a greater whole and is diminished when others are humiliated or diminished when others are tortured or oppressed' (Tutu, 1999:27). In a nutshell, I am convinced that traditional Yorùbá religion comprises of individuals who watch over one another's spirituality, so as to avoid upsetting the spiritual balance. It is precisely this attitude of tolerance that needs to be revived in contemporary Yorùbá living, instead of allowing the inherent tussle and conflict among the Abrahamic monotheisms to pollute their spacetime, leading to loss of love, trust and unity.

Another striking and unique feature of traditional Yorùbá life that has been imported, albeit inadvertently, into modern living, is naming. Surnames of the Yorùbá are loaded with a diversity of antecedents that refer to history, religion, experiences and trade, as well as the family's òrị̣à through which petition to Olódùmarè is made. Naming goes a long way to connecting the contemporary Yorùbá to their traditional heritage. Unless this aspect of naming is retained and sustained too, the pluriverse approach I propose will have little influence.

To appreciate how naming endorses my pluriverse option, I suggest that the reader revisits the story that opened this essay. In the case of Fadilat Abdul-Jeleel Ọșúntọ́lá, Fatimah Ọsṣuntọ́lá, and Peter Fáșínà, one needs no serious intellectual willpower to realise that the one family originates from a history of traditional Yorùbás that worship the goddess Ọsún, whereas the other venerates the god of wisdom, Òrúnmilà, popularly called Ifá sometimes. An analysis of the surnames of each family - 'Ợsúntọ́lá' and 'Fásínà' - reveals more than Christianity and Islam. For the former, there is an attestation that the worship of the female goddess Ọsún was the traditional religion of that family, even before the reception and practice of Islam. Simply, 'Ọsún-to-ólá' translates as 'Ọsún equals wealth'. Hermeneutically speaking, it could also mean that wealth derives from the goddess Ọșún. But who is OȘún? In the words of the custodian of the OSsún Grove, Susanne Wenger (1977:7),

Òsun can be described as the goddess of the waters of life. As she is an Orișa she is supernaturally intense, a metaphysical concentration of a distinct force (sacred force) which also is contained not only in 
man and in all that lives, in all that exists physically, but also in Olodumare, God himself.

Peter Fásínà is also suggestive of a family that boasts of Òrúnmilà, the divinity that channels worship of Olódùmarè. The surname Fásínà is the short form of Ifá-și-ọnà, which means, literally, 'Ifá opened the way.' There is a tendency to 'use of Ifá and Òrúnmilà' (Balogun \& Fayemi 2008:37) to mean one and the same; on the connection between the two terms, Kola Abimbola chronicles,

Another name of Ifá is Orúnmilà. The word Ifá however, is used to refer to the Orisa (divinity) himself, his instruments of divination as well his system of divination and literature. The name Òrúnmilà refers solely to the divinity himself ... Ifá priests and priestesses were counselors, physicians, historians and philosophers of ancient Yorùbá land (Abimbola 2006:119).

The thrust of the philological analysis of the selected Yorùbá surnames serves as a sharp pointer to the peoples' belief in God, contrary to earlier ethnocentric and ethnographic impressions of scholars, such as Edward Taylor, De Brosses, James Frazier and Samuel Baker. It is the failure to comprehend how the Yorùbá construe the divine and reach him via a pantheon of divinities that informs the impression of Samuel Baker, who is reported as saying,

Without exception, they are without a belief in a Supreme Being, neither have they any form of worship or idolatry; nor is the darkness of their minds enlightened even by a ray of superstition. The mind is as stagnant as the morass which forms its puny world (Evans-Pritchard 1965:16f).

Necessarily, one of the realities, among many other realities, portrayed by the pluriverse proposal involves the mutual and peaceful toleration of òriṣà propriety by the traditional Yorùbá. It is my conviction that, if this attitude is revived and applied to contemporary Yorùbá living, the marriage of Peter Fáșínà and Fatimah Ọssúntọ́lá will survive the antagonistic and competitive natures that are natural to foreign religions. Moreover, my pluriverse theory 


\section{Emmanuel Ofuasia}

has the capacity to extinguish quagmires and frictions or hostilities that emanate from religion. To amplify this point, I refer to two types of divinities in traditional Yorùbá religion and spirituality: primordial and personified.

The primordial are the ones that were present, with Olódùmarè, from the beginning of creation or the world; the most popular ones are Órúnmilà, Ajàlá, Obàtálá, and Eșù. The personified òriṣàs, on the other hand, comprise mortal men and women who, during their earthly existence, performed great deeds and wonders, thus, prompting their elevation to òị̀à status. Prominent òrìsàs are Ògún and Sàngó. I tender that the persistence of personified òriṣàs in traditional Yorùbá religion and spirituality not only strengthens my pluriverse thesis, but advocates for a revision of the Abrahamic monotheism among the contemporary Yorùbá, in order to extinguish all manner of friction and enmity culminating from religion.

How does this work? Since the scourge of religious conflict did not exist among traditional Yorùbá, owing to the perception that Òrìsà propriety is a means of venerating Olódùmarè, the Abrahamic monotheisms and their institutions in contemporary Yorùbá societies may glean some truths or principles for their utility. Specifically, if a contemporary Yorùbá, who is now a fervent Christian or Muslim, seeks an end to the religious conflict emanating from these monotheisms, they may entertain that Jesus the Messiah, and the Prophet Muhammad $(S A W)$ are personified divinities. Hence, these popular historic and religious figures are like any other personified òrișà, since they each serve as a channel to the Higher Being. At this juncture, the debate whether or not God is one or many does not surface. Jesus the Messiah and Prophet Muhammad $(S A W)$ are admitted even by followers of Christianity and Islam as means to the Divine and not God themselves. If they employ this strategy, there is no need for the rampant religious conflict and hostilities in recent times. All 'òrìsàs', whether 'imported' or indigenous, will serve as equal, alternative and plausible means to reaching the Supreme Being, with none purporting to wield a unique and forceful hegemony over others.

\section{Conclusion}

I commenced this discussion with a story that is reminiscent of one of the countless ways that the Abrahamic monotheisms cause violent clashes in contemporary Yorùbá society. I also hinted that the contemporary Yorùbá is 
ignorant of their traditional heritage, owing to the influence of the foreign religions. In the face of the persistent struggles by each of these monotheisms to be the one, true religion, countless Yorùbá lives have been cut short. However, my pluriverse option, which I believe is an improvement on the bulk of discourses on religious pluralism, has the potential to smother conflict and violent confrontations that emanate from religious antagonism and competitiveness. My approach is also pragmatic, at least within the domain of Yorùbá space-time. From the arguments I have marshalled so far, two possibilities are obvious: Either the modern-day Yorùbá entertains the view that Jesus and Muhammad are personified òrișà, thereby extinguishing religious conflict and hegemony, or they retain the four common denominators of the monotheisms, and continue to wallow in sheer ignorance and death. However, for my pluriverse theory to gain a foothold for contemporaneous utility, I recommend the first option. Obviously, the entire gamut of this inquiry had been committed to that cause.

\section{References}

Abimbola, K. 2006. Yorùbá Culture: A Philosophical Approach. Birmingham: Iroko Academic Publishers

Akintola, A. 1999. Yorùbá Ethics and Metaphysics. Ogbomosho: Valour Publishing Ventures.

Atanda. J. 1990. An Introduction to Yoruba History. Ibadan: Ibadan University Press.

Balogun, O.A. \& A.K. Fayemi 2008. The Relevance of Ifá to Jurisprudence and Human Rights Discourse. (The International Conference on Philosophy and the Law in Africa 2008.)

Beier, U. 1975. The Return of the Gods: The Sacred Art of Susanne Wenger.

Cambridge: Cambridge University Press.

Bewaji, J.A.I. 2007. An Introduction to the Theory of Knowledge: A Pluricultural Approach. Ibadan: Hope Publication.

Bukari, K.N. 2013. Exploring Indigenous Approaches to Conflict Resolution:

The Case of the Bakwa Conflict in Ghana. Journal of Sociological Research 4,2: 86 - 104. https://doi.org/10.5296/jsr.v4i2.3707

Cobb, J. 1999. Transforming Christianity and the World. Knitter, P. (ed.). New York: Orbis. 
D'Costa, G. 1990. Christian Uniqueness Reconsidered: The Myth of a Pluralistic Theology of Religions. Maryknoll, NY: Orbis Books.

Erlewine, R. 2010. Monotheism and Tolerance: Recovering a Religion of Reason. Indianapolis: Indiana University Press.

Escobar, A. 2010. Latin America at a Crossroads. Cultural Studies 24,1: 1 65. https://doi.org/10.1080/09502380903424208

Fanon, F. 2008. Black Skin White Masks. London: Pluto Press.

Griffin, D.R. 1998. Process Philosophy. In Craig, E. (ed.): Routledge Encyclopedia of Philosophy. London: Routledge.

Erlewine, R. 2010. Monotheism and Tolerance: Recovering a Religion of Reason. Indianapolis: Indiana University Press.

Evans-Pritchard, E.E. 1965. Theories of Primitive Religion. London: Oxford University Press.

Fayemi, A.K. 2012. A Hermeneutico-Reconstructionist Method as a Synthesis of Wiredu's and Oluwole's Methodological Orientation in African Philosophy (PhD Thesis). Olabisi Onabanjo University.

Habermas, J. 1996. A Genealogical Analysis of the Cognitive Content of Morality. In Cronin, C. \& P. Greiff (eds.): The Inclusion of the Other. Cambridge: Massachusetts Institute of Technology.

Habermas, J. 2002. Transcendence from Within, Transcendence in this World. In Mendieta, E. (ed.): Religion and Rationality: Essays on Reason, God, and Modernity. Cambridge: Massachusetts Institute of Technology Press.

Hick, J. 1980. God has Many Names. Philadelphia: Westminster Press. https://doi.org/10.1007/978-1-349-16308-3

Hick, J. 2010. Religious Pluralism. In Taliaferro, C., Draper, P. \& Quinn, P.L (eds.): A Companion to Philosophy of Religion. Oxford: WileyBlackwell

Hick, J. 1989. An Interpretation of Religion. London: Yale University Press. https://doi.org/10.1057/9780230371286

Hick, J. 1985. Problems of Religious Pluralism. New York: St. Martin's Press. https://doi.org/10.1007/978-1-349-17975-6

Isichei, P. 1983. A History of Nigeria. London: Longman.

Jaffee, M. 2001. One God, One Revelation, One People: On the Symbolic Structure of Elective Monotheism. Journal of the American Academy of Religion 69,4: 753 - 775.

https://doi.org/10.1093/jaarel/69.4.753 
Kaunda, C.J., Y.J. Luxman \& R.R. Hewitt 2018. 'The Male Goat that Stops Fighting': The Pyem Philosophy of Reconciliation and Conflict Resolution. Pharos Journal of Theology 99: 1 - 12.

Langerak, E. 2010. Theism and Toleration. In Taliaferro, C., P. Draper \& P.L. Quinn (eds.): A Companion to Philosophy of Religion. Oxford: Wiley-Black.

Locke, J. 1983. A Letter Concerning Toleration. Tully, J.H. (ed.). Indianapolis: Hackett.

Mala, B. \& Z.I. Oseni 1984. Religion, Peace and Unity in Nigeria. Ibadan: National Research Publishers.

Massignon, L. 1994. The Passion of al-Hallaj: Mystic and Martyr of Islam.

New Jersey: Princeton University Press.

Mbiti, J.S. 1969. African Religions and Philosophy. London: Heinemann.

Mill, J.S. 1978. On Liberty. E. Rapaport (ed.). Indianapolis: Hackett.

Nuzhat, F. 2014. Religious Conflict in Nigeria and their Impacts on Social Life. Global Journal of Arts, Humanities and Social Sciences. 2,4: 15 19.

Ofuasia, E. 2020. Monotheism and Metaphysics in the Yorùbá Thought System: A Process Alternative. Journal of Contemporary African Philosophy (JOCAP) 1,1: Available at:

https://journal.domuni.eu:443/jocap/index.php?id=176

Ofuasia, E. 2019. The Metaphysical Implications of the Parallels between Traditional Yorùbá Theology and Process Theology. LASU Journal of Philosophy 2,1: 69 - 83.

Ogunnaike, O. 2015. Sufism and Ifa: Ways of Knowing in Two West African Intellectual Traditions. (PhD Thesis). Harvard University. Available at: http://nrs.harvard.edu/urn-3:HUL.InstRepos:23845406

Oladipo, O. 2004. Religion in African Culture: Some Conceptual Issues. In Wiredu, K. (ed.): A Companion to African Philosophy. New York: Blackwell Publishing.

Querejazu, A. 2016. Encountering the Pluriverse: Looking for Alternatives in Other Worlds. Political International Journal 59,2: 1 - 16.

https://doi.org/10.1590/0034-7329201600207

Paden, J. 2015. Religion and Conflict in Nigeria. Special Report. Washington D.C.: United States Institute of Peace.

Ramose, M.B. 2012. Reconciliation and Reconciliation in South Africa. Journal on African Philosophy 1,5. 
Ratzinger, J. 2004. Truth and Tolerance: Christian Belief and World Religions. San Francisco: Ignatius Press.

Rousseau, J.J. 1997. On the Social Contract. In Gourevitch, V. (ed.): Rousseau: The Social Contract and Other Later Political Writings. Cambridge: Cambridge University Press.

Rowland, A. 1994. Understanding Yoruba Art and Aesthetics. African Arts 27,3: 68 - 78. https://doi.org/10.2307/3337203

Scanlon, T. 1996. The Difficulty of Tolerance. In D. Heyd (ed). Toleration: An Elusive Virtue. New Jersey: Princeton University Press.

Shitta-Bey, O.A. 2013. A Critique of Maduabuchi Dukor's 'Divination: A Science or An Art? Open Journal of Philosophy 3,1: 77 - 80.

https://doi.org/10.4236/ojpp.2013.31A012

Sindima, H.J. 1995. Africa's Agenda: Legacy of Liberalism and Colonialism in the Crises of African Values. London: Greenwood Press.

Sogolo, G.S. 1993. Foundations of African Philosophy: A Definitive Analysis of Conceptual Issues in African Thought. Ibadan: University of Ibadan Press.

Tafese, T. 2016. Conflict Management through African Indigenous Institutions: A Study of the Anyuaa Community. World Journal of Social Sciences 3,1: 22 - 32. https://doi.org/10.5430/wjss.v3n1p22 Tutu, D. 1999. No Future without Forgiveness. New York: Doubleday. https://doi.org/10.1111/j.1540-5842.1999.tb00012.x

Wenger, S. 1977. The Timeless Mind of the Sacred: Its New Manifestation in Osun Groves. Ibadan: Institute of African Studies, University of Ibadan.

Emmanuel Ofuasia Doctoral Candidate Philosophy Department Lagos State University Nigeria ofuasia.emma@yahoo.com 